\title{
A Constitutional Court Decision Has Final Law And Binding Related to Decision No. 57/PHP.BUP-XIX/2021, North Halmahera Election Results Disputes
}

\author{
Selfianus Laritmas ${ }^{1}$, I Gede Yusa ${ }^{2}$, Dewa Gde Rudy ${ }^{3}$, Ahmad Rosidi ${ }^{4 *}$ \\ ${ }^{1}$ Lecturer of the Faculty of Law, University of Halmahera, Indonesia \\ ${ }^{2}$ Professor of Law, Department of Constitutional Law, Faculty of Law, Udayana University, Bali, Indonesia \\ ${ }^{3}$ Lecturer of the Faculty of Law, Udayana University Bali, Bali, Indonesia \\ ${ }^{4}$ Lecturer of the Faculty of Law, University of Gunung Rinjani, , Indonesia \\ *Corresponding author: \\ Email: ahmadrosidi1001@gmail.com
}

\begin{abstract}
Constitutional Court Decision(MK) who is final and binding as stated in Article 24 C paragraph (1) of the 1945 Constitution of the Republic of Indonesia, and Saccording to the provisions of article 47, and explanation of article 10 paragraph (1), Law no. 24 year 2003. The final nature of this Constitutional Court decision includes binding legal force (final and binding).. It turns out, in amarConstitutional Court Decision No 57/PHP.BUP-XIX/2021 cause new legal problems or conflicts of norm because it does not yet have final and binding power in the North Halmahera election dispute, because the Constitutional Court's decision still opens the opportunity for new applications to be resubmitted in the Constitutional Court. MKNumber 14/PHP.BUP-XV/2017, and Decision Number 42/PHP.BUP-XV/2017, on amarthe decision is very clear, the decision has binding power after the decision so that the Constitutional Court can no longer re-hear the election results case after the PSU has been carried out, only the determination is carried out after the KPUD reports the PSU results. This study aims to analyze, first,Is the Constitutional Court's decision no longer final and binding in dealing with regional election disputes, especially the North Halmahera regional election dispute, second, how are the legal problems of the Constitutional Court's decision which is no longer final and binding?. This research is qualified into normative legal research, with an approach Legal approach (Statute Approach), Concept Approach and Case approach. The results of the study show, firstly, that the Constitutional Court's decision creates new legal problems in its decisions which are different from the previous decisions, Second, there is a need for Consistency of the Constitutional Court in deciding disputes that are final and binding so that it does not cause new problems in constitutional law.
\end{abstract}

Keywords: The decision of the Constitutional Court, final and binding.

\section{INTRODUCTION}

In accordance with the provisions of Article 24C paragraph (1) of the 1945 Constitution, the Constitutional Court, hereinafter referred to as the Constitutional Court, has the authority to adjudicate at the first and final levels whose decisions are final to examine the law against the Constitution, to decide on disputes over the authority of state institutions whose authority is given by the Constitution, decides on the dissolution of political parties, and decides on disputes regarding the results of the general election. The decision of the Constitutional Court is regulated separately in Law Number 24 of 2003 concerning the Constitutional Court (UU MK) which was last amended by Government Regulation in Lieu of Law (PERPU) Number 1 of 2013 concerning the Second Amendment to Law Number 24 of 2003 regarding the Constitutional Court, which Perpu 1/2013 has been stipulated as law by Law Number 4 of 2014 concerning Stipulation of Government Regulation in Lieu of Law Number 1 of 2013 concerning Second Amendment to Law Number 24 of 2003 concerning the Constitutional Court Became Law. ${ }^{1}$ Literally, the Constitutional Court's decision which is final and binding has its own legal meaning. The phrase "final" according to the Big Indonesian Dictionary is defined as "the last of a series of examinations" while the phrase binding is defined as "tighten up" "to unite". Starting from this 
meaning, the final phrase and binding phrase, are related to each other as on two sides of a coin meaning the end of an examination process, has the power to bind or unite all wills and cannot be disputed.

${ }^{2}$ Talking about the final and binding nature in a decision, it is one of the powers of the Constitutional Court which has been regulated in the Constitutional CourtElucidation of Article 10 paragraph (1) of the Constitutional Court Law, the concept refers to the principle of administering judicial power, namely holding courts to examine, hear, and decide cases, while still referring to the principle of administering judicial power, which is carried out simply and quickly. The Constitutional Court's decision, which is final and binding, cannot be released on the principle of erga omnes which is defined as binding in general and binding on the object of dispute. Therefore, the decision of the Constitutional Court has the power to legally bind all components of the nation, including the object in dispute ${ }^{3}$.The Constitutional Court's decision which is final and binding has not yet been seen in the Constitutional Court's Decision No. 57/PHP. Bup/XIX/X/2021, March 22, 2021, on the decision of point 5 of the Constitutional Court,

"Ordering the General Election Commission of North Halmahera Regency to combine the results of the re-voting as referred to in paragraph 3 and the voting as referred to in paragraph 4 with the results determined by the Respondent as stated in the Decision of the General Election Commission of North Halmahera Regency Number 358/PL. 06.2-Kpt/8203/KPU-Kab/XII/2020 concerning Determination of the Recapitulation of Vote Counting Results and Results of

the 2020 Regent and Deputy Regent Elections, dated December 16, 2020, which were not canceled by the Court and then put them in a new decision regarding the final vote results each pair of candidates

in the 2020 North Halmahera Regent and Deputy Regent Election, and then announce it in accordance with the laws and regulations without having to report to the Court."

${ }^{4}$. In this decision, the KPUD legally gives authority to the KPUD in addition to carrying out re-election (PSU), as well as giving the right to combine the results of the PSU votes with the results of the votes that were not canceled in the previous Pilkada. Then determine who/or which pair of candidates for regent gets the most votes.Based on the ruling, it has not provided legal certainty in the completion of the North Halmahera Pilkada because the decision provides new opportunities for the losing candidate to submit a new application. According to the decision, the pair Frans Manery and Muchlis Tapi Tapi (FM MANTAP) received the most votes and were designated as the chosen pair of candidates. Based on this fact, the candidate pair for Regent and deputy regent, Joel Wogono and Said Bajak (JOS) were dissatisfied and filed an objection to the dispute to the Constitutional Court and asked for the PSU results to be canceled/or the FM-MANTAP pair disqualified.In the decision of the Constitutional Court Number 57/PHP. Bup/XIX/X/2021, Different from the paradigm of the previous 5 (five) years of the Constitutional Court's decisions as in the Constitutional Court's DecisionNumber 14/PHP.BUPXV/2017, regarding the PHP case of the Regent and Deputy Regent of Tolikara Regency, Papua Province in 2017, and Decision Number 42/PHP.BUP-XV/2017 regarding the PHP case of the Regent and Deputy Regent of Puncak Jaya Regency, Papua Province In 2017, the decision of the Constitutional Court was very clear, which ordered

"To the KPUD to carry out the PSU, the results are brought to the Constitutional Court to make a final decision by determining the actual vote results from the parties/pairs of candidates in dispute, after that the KPUD holds a plenary meeting to determine/or make a decision regarding the pair that received the most votes.".

This different Paradigm of the Constitutional Court Decisions shows the existence of the Constitutional Court Decisions, which are final and binding in nature, which are doubtful in the settlement of regional election disputes, this is a bad precedent for the existence of the Constitutional Court, especially in enforcing the 
implementation of the Court's decisions. constitutional mandate. The Constitutional Court seems to want to crash its own existence as the first and last judicial institution in deciding disputes over the results of the Regional Head Elections. it should be based on the a quo decision number 5 in the decision to provide legal certainty to the North Halmahera KPUD as the main address to execute the Constitutional Court's decision as a final decision without having to give room for legal remedies to return to the parties who feel aggrieved. "Indeed, in the Constitutional Court's decision that provides space, the existence of the Court is no different from that of a general court whose decision can be appealed. If this is the case, then the law enforcement model in the Constitutional Court is no longer sacred because the tendency for the final decision to be annulled by the Constitutional Court itself.

\section{Formulation of the problem}

Based on this background, this research will focus on the problem formulated as follows

a. Is the Constitutional Court's Decision no longer final and binding in dealing with Pilkada disputes?

b. How are the legal problems of the Constitutional Court Decisions which are no longer final and binding?

\section{METHODS}

The research method used in this research is normative juridical research using the statute approach, the concept approach and the case approach. ${ }^{5}$ therefore the target of this research is law or norm. The definition of rules includes legal principles, rules in a narrow sense (value), concrete legal regulationsThe Decision of the Constitutional Court which is final and binding in relation to the decision on the dispute over the results of the 2020 regional elections, which has the object of normative law in the form of legal principles and the legal system, which examines the rule of law, legal theories, documents, and articles related to the Constitutional Court ${ }^{6}$.

\section{RESEARCH RESULTS AND DISCUSSION}

a. Powers and powers of the Constitutional Court

The Constitutional Court is an independent judicial authority to administer justice to uphold law and justice. The Constitutional Court was formed to guarantee the constitution as the highest law so that it can be enforced, so that the Constitutional Court is called the guardian of the constitution. The authority of the Constitutional Court is at the same level as the Supreme Court as an independent judicial power in the Indonesian constitutional system. In exercising its authority, which includes reviewing laws against the basic constitution, the Constitutional Court also interprets the constitution, so it is called the Sole Interpreter of the Constitution. ${ }^{7}$ As the sole interpreter of the constitution, many things in adjudication have consequences for other powers in a position against each other, especially on the legislature where their products are reviewed.The position of the Constitutional Court in the Indonesian constitutional system is as a state institution that carries out judicial functions with the competence of the object of constitutional cases. The existence of the Constitutional Court is understood as a guardian of the constitution to strengthen the basics of constitutionalism in the 1945 Constitution. Therefore, the Constitutional Court has authority with clear boundaries as a form of respect for constitutionalism. The limits of authority possessed by the Constitutional Court as a judicial institution are a form of the implementation of a balance of power system among state institutions (checks and balances).The Constitutional Court as one of the actors of judicial power is expected to be able to restore the image of the judiciary in Indonesia as an independent judicial power that can be trusted in upholding law and justice. The establishment of the Constitutional Court in Indonesia, the most important thing is to ensure that 
there are no laws that are contrary to the Constitution and if there are conflicts, the authority of the Constitutional Court is to cancel them.

That is why, it is often said that the Constitutional Court is the guardian of the constitution and the sole (binding) interpreter of the constitution. ${ }^{8}$ The positive response from the community is a response to the opening of the door to democracy, so that various legal instruments which according to the community's assessment are contrary to justice and human rights which are upheld and regulated in the 1945 Constitution of the Republic of Indonesia. ${ }^{9} \mathrm{An}$ independent judicial power is very important to be stated in the Constitution because without the freedom of judicial power it is very difficult to produce court decisions that reflect legal justice.According to the provisions of article 29 paragraph (1) of Law no. 48 of 2009 concerning Judicial Powers states that: The Constitutional Court has the authority to adjudicate at the first and final levels whose decisions are final to: (1) examine the Act against the 1945 Constitution of the Republic of Indonesia; (2) decide on disputes over the authority of state institutions whose authorities are granted by the 1945 Constitution of the Republic of Indonesia; (3) decide on the dissolution of a political party; (4) decide disputes regarding the results of the general election; and (5) other powers granted by law. The function of the Constitutional Court is to maintain the implementation of a responsible government, as well as the proper role that can be carried out by the Constitutional Court as one of the actors of judicial power, also serves to encourage the mechanism of checks and balances in the administration of the state, maintain the constitutionality of the exercise of state power and function in the context of the realization of a democratic, prosperous and just Indonesian legal state. The function of the Constitutional Court is as follows: ${ }^{10}$

first As mentioned above, in encouraging the check and balance mechanism, the Constitutional Court is carried out through its authority to examine laws against the Constitution, to decide on disputes over the authority of state institutions whose authority is granted by the Constitution, and in deciding the opinion of the DPR regarding alleged violations by the president. and/or vice president as regulated in Article 7A and Article 7B of the 1945 Constitution.

Second, the function of maintaining the constitutionality of the implementation of state power is carried out by the Constitutional Court in carrying out all the authorities and obligations as referred to in Article 24C paragraph (1) and paragraph (2) of the 1945 Constitution. This role demands the functions and responsibilities of the Constitutional Court as one of the actors of judicial power in addition to MA.

Third, the function of the Constitutional Court together with other state institutions is consciously and actively bringing the Indonesian state to the goals of the state and the ideals of the proclamation, namely to create a welfare state as mandated by the 1945 Constitution. This role is a consequence of the Constitutional Court's position as a state institution. Based on this view, the function of the Constitutional Court is as a guardian or guardian of the constitution, and upholds the principle of the rule of law in the Indonesian constitutional system. to realize the ideals of a democratic rule of law. An affirmation was also conveyed by Ni"Matul Huda. ${ }^{11}$ that: Indonesia is a state of law, as well as a statement that judicial power is an independent power, contains the spirit not to use the law as a tool of power, uphold the principle of equality before the law and protect internal and external interference with the judiciary in order to prevent and avoid failure to achieve justice.

Based on the above thought, the attributive authority of the Constitutional Court is only obtained from the 1945 Constitution which means that the 1945 Constitution also limits the authority of the Constitutional Court (attributive-limitative). So that the existence of the Constitutional Court in the life of the state is very important in protecting and carrying the voice of the people. With its decisions, the Constitutional Court is a 
concrete answer to all the problems that occur in the midst of society against laws that are considered by citizens to be contrary to the constitution.

\section{b. The nature of the authority of the Constitutional Court which is final and binding in the dispute over the results of the North Halmahera election}

Constitutional Court decisions include type of final decision. It can be seen in the provisions of the Court's procedural law The constitution stipulates that every The Court's decision is final and binding (final and binding). In law testing tradition, of course no known interim decision (provision). const courtiknow the verdict while (interrupted)) (authorized to issue decision provisi) only on case authority disputes between state institutions, whose authority is granted by constitution.Meanwhile, in the case of a petition for judicial review of the Constitution, it is only known that there is a final decision. This is in accordance with the provisions that apply to the mechanism for reviewing laws owned by the Constitutional Court, that the Law that is being reviewed by the Constitutional Court remains valid, before a decision is made stating that the Law is contrary to the Constitution., so don't havei binding legal force ${ }^{12}$ When viewed from the ruling, the decision of the Constitutional Court is included in the type of decision that is declaratory in natureconsttnaive.It is declaratory in nature, meaning a decision where the judge simply states what is the law, does not carry out a sentence. This can be seen in the decision on the judicial review which states that the content material, paragraph, Articles, and or parts of the law do not have binding legal force. Constitutive means a decision that states the absence sa legal situation and/or create a new legal situation, this is the excess of a decision that isclaratoir 13 " So, whenito a court decisionThe constitution states a law not binding, because it contradicts with the Constitution, then automatically the decision also at the same time create a situation the new law.

The authority of the Constitutional Court in the constitutional system as a constitutional court, is different from the general court or ordinary court. The nature of the decision of the Constitutional Court determined is final and no other legal remedies. different from the agency's decision judiciary within the Supreme Court (MA) which still provides other legal remedies in the form of appeals, cassation, including the mechanism for Judicial Review (PK) and/or through clemency. The specificity of the final character in the Constitutional Court Decision, is emphasized in Article 24C Paragraph (1) The 1945 Constitution of the Republic of Indonesia. These provisions are then stated in Article 47, and an explanation of Article $10 \mathrm{U}$ MK, emphasizes the final nature, Based on these provisions, the final character shows at least 3 (three) things, namely (1) The Constitutional Court's decision has legal force directly when spoken in court; (2). The Constitutional Court's decision is binding on all parties and has legal consequences for all parties concerned with the verdict. $3)$. The Constitutional Court's decision requires all parties to comply with and implement ${ }^{14}$. According to Bambang Sutiyoso, the final decision means that the decision of the Constitutional Court is the first resort and the last resort for justice seekers. ${ }^{15}$ So that The juridical consequences of the provisions as described above are that the Constitutional Court's decision has final and binding force and there has been no further legal action since the decision has been pronounced in a plenary session which is open to the public. ${ }^{16}$

Another problem that often comes The Constitutional Court's decision is the obscurity of its decision, the result is an expected decision will solving the problem actually makes new problems, such ason The Constitutional Court's Decision Number 57/PHP. Bup/ XIX/ X/2021, dated March 22, 2021, regarding the Dispute over the results of the North Halmahera election, which in the Court's decision ordered the North Halmahera KPUD to conduct a re-election (PSU) and then announced it based on statutory regulations without having to report to Court. Meaning The use of the word without having to report to the Court, gives its authority 
to the KPUD as the main address to complete the PSU stage. On the order of the Court, the KPUD as the organizer has made a special norm to organize the PSU stages. So in this context, the actions of the North Halmahera KPUD as the main address should be appreciated because of its commitment to implementing the Court's decision, The Court's action in its decision to implement this PSU, it seems that the Court is not committed to its own decision. This attitude certainly gave birth to various interpretations by the public of the existence of the Court in resolving this case. One of the reasons for this interpretation is that the Court's attitude tends not to implement its decisions, which clearly have permanent legal certainty when viewed from the rulings. For example, in the process of settling the results of the Regional Head Elections, the Court still provides space in its decision to accept the application for the Dispute over the results of the Pilkada Volume 2, it is conceivable that this dispute resolution system is very convoluted and there is no legal certainty.

The disputed case for the Halut Regional Head Election provides a note that it turns out that the Constitutional Court's decision is not final and binding because there are still further legal remedies after the PSU implementation. The assumption of this legal process is because the basis is the attitude of the Court which has already provided space for further dispute over its final decision, because it will be used as jurisprudence for the parties to the dispute in the dispute over the results of the election in the future.In the context of the Halut Election Result Dispute (PHP) case, the Court should have given full authority to the Halut KPUD to carry out the stages based on the regulations it regulates. Of course, this regulation is a new norm and specifically for the PHP stage based on the final court decision. The Halut PHP case is actually considered odd because the KPUD's authority as a regulator of the Pilkada administration seems to have been taken over by the Court by making one stage of dispute resolution on the results of the further Pilkada which of course is not specifically regulated, either in the Court's decision or in the PSU stage by the Halut KPU. In this context, it is logical that later elected regional heads from the PSU will be sworn in because they have carried out the stages according to the special norms set by the Halut KPU.In relation to the above, Mukthie Fadjar stated: ${ }^{17}$ The explanation of the Constitutional Court Law in its explanation generally emphasizes several points of direction regarding the Constitutional Court of the Republic of Indonesia being the guardian of the constitution, namely: a) so that the constitution is carried out responsibly in accordance with the people's will and ideals. Democratic ideals, b) maintaining a stable state government, and c) a correction to the past experience of state administration caused by double interpretations of the constitution.Therefore, the thought of the need to provide room for other legal remedies for the Constitutional Court's decision is something that cannot be justified because it does not has a constitutional basis. In accordance with the Constitution, let alone other parties, the Constitutional Court itself is not given the authority to review the decisions that have been handed down.

Hence, will to file other legal remedies against the Constitutional Court's decision means having to first change the constitutional provisions. This is in line with the opinion Sri Soemantri Martosoewignjo who stated, whatever the reason, the Decision The Constitutional Court is final and binding. There are no other legal remedies, including PK though. If you want the Constitutional Court's decision to be PKed, that's the only way is to amend the 1945 Constitution. Because, in According to the 1945 Constitution, the Constitutional Court's decision is determined to be final.Therefore, in the settlement of regional election disputes, the decision of the Constitutional Court, which is final and binding, must contain 4 (four) legal meanings in order to provide legal certainty, namely: a) realizing legal certainty as soon as possible for the disputing parties. b), the existence of the Constitutional Court as a constitutional court. c), means as a form of social control carried out by the Constitutional Court. d) as the sole custodian and interpreter of the constitution.Basically, the decision of the Constitutional Court which is final and binding (binding), gave birth to a number of legal consequences in its application, namely the decision of the Constitutional Court which resulted in positive legal consequences and negative legal consequences. The legal consequences that have a positive meaning are: Ending a legal dispute; 
Keeping the principlechecks and balances; and Encouraging the political process. Meanwhile, the legal consequences of the Constitutional decisions which are final and binding (binding) are not only limited to decisions on paper, but can also be carried out effectively in their implementation (implementative).

\section{c. The Problematic of the Constitutional Court's Decision Final and Binding}

Problems that arise as a result of the Constitutional Court's decision which is not final in The Constitutional Court's decision was in the dispute over the results of the North Halmahera regional election Number 57/PHP. Bup / XIX / X / 2021 dated March 22, 2021, caused several new problems in the authority of the Constitutional Court as the guardian of the constitution including,

First, philosophical problem. The decision of the Constitutional Court in The verdict is Number 57/PHP. Bup/XIX/X/2021 dated March 22, 2021, it is not final to end the election dispute, it should have been decided by the Constitutional Court as the previous decision which was valid for 5 years in accordance with the Pikaada dispute thatis final and obtain permanent legal forcesince it was pronounced, and there is no other legal remedy that can be taken as described in Article 47 and the explanation of Article 10 paragraph (1), of the Constitutional Court Law. but the reality that occurred in the dispute over the election results in North Halmahera district still leaves problems. Caused in the decision of the Constitutional CourtNumber 57/PHP. Bup / XIX / X / 2021, the Court is inconsistent with the nature of its decision which is final and binding, so that legal certainty in this election dispute is complicated, for example, it is almost the same as the general court.

The Court's decision, in contrast to the previous Constitutional Court Decisions that tried the same regional election dispute case, namely the Constitutional Court DecisionNumber 14/PHP.BUP-XV/2017, concerning PHP Regent and Deputy Regent of Tolikara Regency, Papua Province, Year 2017, and Decision Number 42/PHP.BUP-XV/2017 concerning PHP Regent and Deputy Regent of Puncak Jaya Regency, Papua Province Year 2017, which in its decision is quite firm in describing its final and binding nature, so that after the Constitutional Court's decision no other legal remedies will be taken. ${ }^{18}$ This emphasizes that the 2017 Constitutional Court Decision, the position of the decision can be final and binding, so that the dispute over the results of the regional election in question inThe Constitutional Court has legal certainty, therefore the Constitutional Court must remain consistent with its legal authority so that justice seekers continue to believe in the power of the decision which is final and binding, so that the public or interested parties can accept every decision of the Constitutional Court properly so that they cannot act. nothing because justice has been shackled by the verdict. Because of thataccording to Gustav Radbruch which must be achieved in the legal objectives for the justice-seeking community is that it needs to be oriented to three things, namely legal certainty, justice, and usefulness/usefulness (doelmatigheid). ${ }^{19}$

According to Radbruch, legal certainty is the main guide to the law, so that the law becomes positive, in the sense that it applies with certainty. The law must be obeyed, thus the law is truly positive. ${ }^{20}$ The law is required to have certainty with the intention that the law must not change. A law that has been enacted will be binding on everyone and will remain until the law is withdrawn. The problem that occurs as a result of misunderstanding the meaning of legal certainty is, often the sound and even the editorial nature of an article in the law are absolutely preserved, so that what happens is as there is a saying: lex duras sed tamen scripta, which means the law is harsh, but like it or not, that's how it sounds.In accordance with the thoughts explained by Radbruch, legal certainty in deciding the results of the North Halmahera election, the judge should remain consistent with the previous decisions so as not to cause double interpretations in the settlement of the election results, as a result of different decisions causing new legal problems in the Constitutional Court's decision which is final and binding, as a result the meaning of legal certainty that will be achieved in the dispute over the election results will not be achieved, this is very contrary to the legal objectives described by Radbruch. 
Second, juridical problem. When examined from the aspect of the legal consequences, the Constitutional Court's decision which is final and binding no longer provides legal certainty and creates a new precedent in the examination of regional election disputes, because in its decision the Constitutional Court can annul its decision, as a result in the North Halmahera PHP decision, there is still room for by the Constitutional Court when the losing party in the re-election of votes, can still submit a new application in the election dispute. This actually creates legal uncertainty in the dispute over the election results because the previous Constitutional Court's decision was final and binding very visible but in the final decisionnumber 57/PHP. Bup/ XIX/ X/2021 creates a new interpretation because the Constitutional Court's decision can still be annulled after the re-election results.

Third, social problems. Legal uncertainty emerged in the dispute over the results of the regional election in North Halmahera Regency, actually making the legal, social, political, economic, security, unity and integrity situation worse. chaos. When the economic, social, political and legal situation becomeschaos it is difficult to predict legal behavior so that there will be chaos in the life of society, nation and state so that many social problems arise. This is because the public will claim each other that the Constitutional Court's decision does not apply immediately the same as the previous decision, thereby causing unrest in the community due to the Constitutional Court's decision which does not apply the same as the previous one.

Fourth, political problem. The juridical essence of the final decision of the Constitutional Court can no longer have a special meaning in accordance with the nature of the Constitutional Court's decision, learning from the Constitutional Court's Decision for North Halmahera PHP, the public may interpret that the Constitutional Court's decision can be changed if it is close to party officials or parties. who has the power, this has a tendency that the Constitutional Court can no longer be trusted as the guardian of the constitution, even though the binding power of the Constitutional Court Decision is erga omnes as stated by SF Marbun. Who quoted Bagir Manan's opinion during a public lecture at the Faculty of Law, Admajaya University, Yogyakarta on February 19, 1994 which stated that: One of the positive aspects of decisions with the character of erga omnes is the existence of legal certainty regarding the position of statutory regulations or administrative actions that are declared unconstitutional. legitimate. While the negative side means that judges are no longer solely responsible for establishing laws (judicial functions), but have developed to carry out the function of forming laws (statutory functions). ${ }^{21}$

From the above view, the Constitutional Court is given the authority to make decisions which can be interpreted as good jurisprudence in the sustainability of the constitutional system. Therefore, in the Constitutional Court's Decision on the Dispute over the results of the North Halmahera election, the Constitutional Court should have remained in its previous decision which no longer caused new problems, based on the authority it has in accordance with Article24C Verse (1) the 1945 Constitution of the Republic of Indonesia, which then enacted the law 24 year 2003.

Based on the problem notes in the North Halmahera PHP Decision, the Constitutional Court's decision which is final and binding becomes a constitutional basis in the dispute over the results of the regional elections in North Halmahera.

a. The final decision of the Constitutional Court is attached to the nature of the position of the Constitution as the highest law so that there is no other law that is higher than him. The meaning of the statement that, when an issue is brought before the Constitutional Court and the Constitution becomes the basis for testing, then the decision on the matter absolutely final.

b. The final nature of the Constitutional Court Decision is to protect and protect the authority of the constitutional court. caused, if the judiciary The constitution accommodates other legal remedies, so there is no difference The Constitutional Court has the same authority with the general court. As a 
result, the parties will be held hostage, in terms of time, energy, as well as costs, all of which are contrary to the principles of justice organized quickly, simply, and low cost.

c. The risk of the Constitutional Court's decision containing errors or Errors cannot be eliminated even though they can be minimized.

According to the thought above, what must be understood is that the judge's decision sometimes causes errors and mistakes, Hal This cannot be separated from the fact that constitutional judges are human ordinary people who naturally have weaknesses that make it possible err. However, regarding this matter, as stated by Moh. Mahfud MD, The Constitutional Court's decision must remain final because, (1) the choice of verdict depending on the perspective and theory used by the judge; (2)judge's law yarfa'ul khilaaf, which means the judge's decision resolves the difference; and (3) there is no better alternative to eliminate the final character so that it requires the Constitutional Court in its decision to be consistent with the final and binding nature of the decision so that there are no prolonged legal problems such as in the North Halmahera PHP.

\section{CONCLUSION}

Based on the analysis as described above, it can be concluded that the decision of the Constitutional Court which is final and binding is the first resort and the last resort for justice seekers, so that the Constitutional Court Decision No.57/PHP.BUP-XIX/2021, related North Halmahera PHP in its decision must describe the final nature andtie like a verdict The previous Constitutional Court was the Constitutional Court Decision nnumber 14/PHP.BUP-XV/2017, and Decision Number 42/PHP.BUP-XV/2017,In order not to give rise to other interpretations which result in the Constitutional Court's decision, it can be adjourned again for trial. This can have a direct consequence that the Constitutional Court's decision does not yet have permanent legal force. Whereas the nature of the Constitutional Court's Decision has been final and binding since it was pronounced in a plenary session which is open to the public. In addition, the main characteristic in binding decisions of the Constitutional Court is that it is erga omnes, so the Constitutional Court's decision that applies to North Halmahera PHP should bedescribes the decision of the Constitutional Court which is final and binding so that it is no longer a double interpretation in the application of the Constitutional Court's decision.

\section{SUGGESTION}

It is hoped that the Constitutional Court's Decision in the upcoming Pilkada Dispute will still describe the essence of the Constitutional Court's decision which is final and binding so that justice seekers do not hesitate in seeking justice in the Constitutional Court as happened in the North Halmahera Pilkada.

\section{REFERENCES}

[1] Anton F. Susanto fund. HR Otje Salman, 2010,The Legal Theory of Remembering, Collecting and Reopening, Refika Aditama, Bandung).

[2] Fajar Laksono, 2013, et al, Implications and Implementation of the Decision of the Constitutional Court Number 5/PUU-X/2012 concerning International Standard Schools (SBI)/International Standard School Pilots (RSBI), Jakarta: Registrar and Secretariat General of the Constitutional Court of the Republic of Indonesia.

[3] Fadjar Mukhtie A., 2004, Keeping the Pulse of the Constitution, One Year Reflections on the Constitutional Court, Constitution Press, Jakarta.

[4] Huda Miftakhul, 2007, Ultra Petita in Judicial Review, in Journal of the Constitution Volume 4 Number 3, Constitutional Court of the Republic of Indonesia, Jakarta.

[5] Hoesein Arifin Zainal, 2009, Judicial Review at the Supreme Court of the Republic of Indonesia Three Decades of Reviewing Legislation, Jakarta: Raja Grafindo Persada.

[6] Big Indonesian Dictionary, 2001,Ministry of National Education and Balai Pustaka, Jakarta,

[7] Latif Abdul, 2009, Functions of the Constitutional Court Efforts to Realize a Democratic State of Law, Yogyakarta: Total Media. 
[8] Malik, 2009, Reviewing the Legal Meaning of Final and Binding Constitutional Court Decisions, Journal of the Constitution, Volume 6 no 1 of 2009,

[9] Marzuki Mahmud Peter, 2016, Legal Research, Prenadamedia Group Publisher, Jakarta.

[10] Mertokusumo, 1996, Chapters About the Discovery of Law, Publisher:Image of Aditya Bakti, Bandung.

[11] Moh. Mahfud MD, 2010, Post-Constitutional Constitutional Law, Jakarta: Rajawali Pers.

[12] Notohamidjojo O., 2011, Basic Questions of Legal Philosophy, Griya Media, Salatiga, 2011,

[13] Siahaan Maruarar, 2005, Procedural law of the Constitutional Court of the Republic of Indonesia. Constitution press, Jakarta

[14] Soeroso Laksono Fajar, 2014, Aspects of Justice in Final Nature Constitutional Court Decision, Constitutional Journal, Volume 11, Number 1.

[15] Sutiyoso Bambang, 2006, Procedural Law of the Constitutional Court of the Republic of Indonesia, First Printing, Bandung: PT. Image of Aditya Bakti.

[16] Tatawu Guasman, 2017, The Legal Essence of the Constitutional Court's Decision on Disputes on Regional Head Elections (Pilkada), Holrev Journal, Volume 1 Issue 2.

[17] 1945 Constitution of the Republic of Indonesia

[18] Law Number 48 of 2009 concerning Judicial Power

[19] Law Number 24 of 2003 concerning the Constitutional Court

[20] Constitutional Court's Decision Number 14/PHP.BUP-XV/2017, regarding the dispute over the results of the election of the Regent and Deputy Regent of Tolikara Regency, Papua Province, 2017,

[21] Decision Number 42/PHP.BUP-XV/2017 concerning Disputes on the Result of the Election of Regent and Deputy Regent of Punjak Jaya Regency, Papua Province in 2007,

[22] Constitutional Court Decision Number 57/PHP. Bup/XIX/X/2021, aboutregarding the dispute over the results of the election of the regent and deputy regent of North Halmahera district in 2020 